\title{
PREVALENCE OF SICKLE CELL ANAEMIA AND THALASSAEMIA IN TRIBAL LAMBADA (BANJARA) COMMUNITY IN WARANGAL DISTRICT, TELANGANA, INDIA
}

\author{
Sudhakar Ajmera1 , Balram Banoth², Ramkishan³, Ravinder Rao ${ }^{4}$ \\ ${ }^{1}$ Associate Professor, MGM Hospital, Kakatiya Medical College, Warangal, Telangana. \\ ${ }^{2}$ Professor and HOD, Department of Paediatrics, Kakatiya Medical College, Warangal. \\ ${ }^{3}$ Medical Officer, Red Cross Society, Warangal. \\ ${ }^{4}$ Chairman, Red Cross Society, Warangal, Telangana.
}

\section{ABSTRACT}

\section{BACKGROUND}

The inherited disorders of Haemoglobin are the most common single gene disorders, which includes sickle cell anaemia and thalassaemia. As per WHO estimates, $4.5 \%$ to $5 \%$ of the world's population are carriers of haemoglobinopathies. In India, 30 million carriers and 15,000 infants with thalassaemia have been reported. There are no studies regarding the prevalence of sickle anaemia and thalassaemia in tribal community of Lambadas in Warangal district of Telangana state.

Hence this, our aim is to bring the baseline data and create the awareness in Lambadas of tribal community of Warangal district in Telangana.

\section{MATERIALS AND METHODS}

This study was conducted to investigate the prevalence of sickle cell anaemia and thalassaemia among Lambada tribes of Warangal district. This is a descriptive cross-sectional study. Data was collected from those who were admitted from September 2014 to December 2015 for anaemia and blood transfusion in district level teaching hospital, Mahatma Gandhi Memorial Hospital, Kakatiya Medical College and from Indian red cross society Warangal, Telangana.

\section{RESULTS}

Total 160 cases were enrolled in this study, out of which 46 (28.75\%) cases were Lambadas (Banjara). Male were 34 (73.91\%), female were 12 (26.08\%), consanguinity 27 (59\%), non-consanguinity 19 (41\%) in Lambadas (Banjara), 35 (76.08\%) cases were diagnosed as thalassaemia and $11(23.91 \%)$ cases were diagnosed as sickle cell anaemia in Lambada group, blood group distribution of 46 cases were A+ve 12 (26.08\%), A -VE 2 (4.34\%), B+VE 16 (34.78\%) and 0+ve 16 (34.78\%).

\section{CONCLUSION}

This study provides the information regarding the prevalence of disease among the Lambada (Banjara) tribe of Warangal district, Telangana state. The prevalence of haemolytic anaemia is $28.75 \%$ (Sickle cell anaemia is $23.91 \%$ and thalassaemia is $76.08 \%$ ) in Lambada children compared to other community in the present study. Highest prevalence rate was seen in single Lambada population. This study is of immense value for future reference and monitoring of these genetic disorders in Lambada (Banjara) population in Telangana state.

\section{KEYWORDS}

Thalassaemia, Sickle Cell Anaemia, Lambada Community, Tribal, Warangal.

HOW TO CITE THIS ARTICLE: Ajmera S, Banoth B, Ramkishan, et al. Prevalence of sickle cell anaemia and thalassaemia in tribal Lambada (Banjara) community in Warangal district, Telangana, India. J. Evolution Med. Dent. Sci. 2017;6(36):2953-2956, D0I: $10.14260 /$ Jemds/2017/636

\section{BACKGROUND}

The inherited disorders of Haemoglobin are the most common single gene disorders, which includes sickle cell anaemia and thalassaemia. Sickle cell anaemia is one of the most common monogenic disorders globally with an autosomal recessive inheritance. James Herrick, a physician first described the characteristic sickle shaped red cells in medical student from Grenada in 1910. The first sickle haemoglobin in India described by Lehman and Cutbush in 1952 in the tribal

Financial or Other, Competing Interest: None.

Submission 30-12-2016, Peer Review 15-02-2017,

Acceptance 21-02-2017, Published 04-05-2017.

Corresponding Author:

Dr. Sudhakar Ajmera,

Associate Professor,

Department of Paediatrics,

MGM Hospital, Kakatiya Medical College,

Warangal, Telangana State.

E-mail: drajmerasudhakar@yahoo.co.in

DOI: $10.14260 /$ jemds $/ 2017 / 636$

(c) (i) $\Theta$ populations in Nilgiri's hills in south India. Linus Pauling and his colleagues showed the sickle haemoglobin ( $\mathrm{HbS}$ ) had unaltered electrophoretic mobility and they were the first to define it as a molecular disease in 1949. In 1957, Vernon Ingram discovered that sickle haemoglobin resulted from a single amino acid substitution in the haemoglobin molecule. This disorder is due to deletion of Beta-globin gene on chromosome 11 valine is substituted for glutamic acid on Beta-polypeptide chain. Under conditions of anoxia and acidosis the erythrocytes are deformed into sickle shaped cells. The distorted cells block the capillaries and cause local anoxia. Anoxia leads to further sickling. Blockage of the capillaries causes infarction in various tissues and organs such as the liver, spleen, muscles and bones. Heterozygotes have a selective advantage and are protected against Plasmodium falciparum malaria, while there is an increased premature death rate of homozygotes.

Thalassaemia is due to reduced synthesis of a globins chain, because of mutations in Beta gene of adult haemoglobin, the Beta chain production is either totally, 
partially or minimally depressed depending upon the mutation. The haemolysis occurs due to imbalance in production of Alpha and Beta chains; since Beta chain synthesis is reduced the excess of Alpha chains produces Alpha tetramers, which get precipitated in red cells. These cells get lysed within the bone marrow before being released as reticulocytes.

These disorders clinically manifested as pallor, jaundice, hepatosplenomegaly, painful crisis, acute chest syndrome, haemolytic facies, growth retardation, frequent infection and in need of repeated blood transfusion.

As per WHO estimates, $4.5 \%$ to $5 \%$ of the world's population are carriers of haemoglobinopathies. The incidence of Beta thalassaemia trait and sickle cell anaemia varies between 3 to $17 \%$ and 1 to $44 \%$ respectively. This is because of high rate of consanguinity.[1,2] The sickle cell trait is very high, $>20 \%$ seen in the Maher, Kurmi, Panka, Otkar, and Pardhan community[3,4]; sickle cell anaemia is predominantly found in tribal population of central and southern part of India. Thalassaemia is common in communities like Sindhi, Parsee, Lohana, Panjabi, Bengalis and Gujarati. ${ }^{[1,5,6,7]}$ In India, 30 million carriers and 15,000 infants with thalassaemia have been reported.

India has the world's second largest concentration of Tribal populations next to Africa. They are believed to be the early settlers in the country and are considered to be the Original inhabitants. In all 461 scheduled tribes have been listed and they have their own characteristic cultural patterns, languages and social systems. Tribal population in India is $10,42,81,034$, constituting $8.6 \%$ of country's population. In Telangana state is 32,89,928 lakhs, $9.34 \%$ of total populations of Telangana state are tribes; 16 major tribal groups are in Telangana, among the total tribal population-

1. Lambadas- $20,46,117(62.19 \%)$

2. Koyas- $4,86,391(14.78 \%)$

3. Gonds- $2,97,864(9.05 \%)$

4. Yerukula- $1,44,128(4.38 \%)$

5. Other sub-castes- $2,64,845$ (8.03\%)

In Warangal district, total tribal population is $5,30,656$. Males are 2,68,576 and females are 2,61,680. Among the tribal population, there are no studies regarding the prevalence of sickle anaemia and thalassaemia in tribal community of Lambadas in Warangal district of Telangana state. Hence this, our aim is to bring the baseline data and create the awareness in Lambadas of tribal community of Warangal district in Telangana.

\section{MATERIALS AND METHODS}

This study was conducted to investigate the prevalence of sickle cell anaemia and thalassaemia among Lambada tribes of Warangal district. This is a descriptive cross-sectional study.

Data was collected from those who were admitted from September 2014 to December 2015 for anaemia and blood transfusion in district level teaching hospital, Mahatma Gandhi Memorial Hospital, Kakatiya Medical College and Indian Red Cross Society, Warangal, Telangana.

\section{RESULTS}

Total 160 cases were enrolled in this study (Graph 1), out of which 46 (28.75\%) cases were Lambadas (Banjara). Graph 2: male were 34 (73.91), female were 12 (26.08). Graph 3: consanguinity 27 (59\%), non-consanguinity 19 (41\%), graph 4: $35(76.08 \%)$ cases were diagnosed as thalassaemia and 11 (23.91\%) cases were diagnosed as sickle cell anaemia. Graph 5: blood group distribution of 46 cases were A +ve, 12 (26.08\%) A -ve, 2 (4.34\%) B +ve and $16(34.78 \%) 0+v e$.

\section{distribution of cases in various communities}

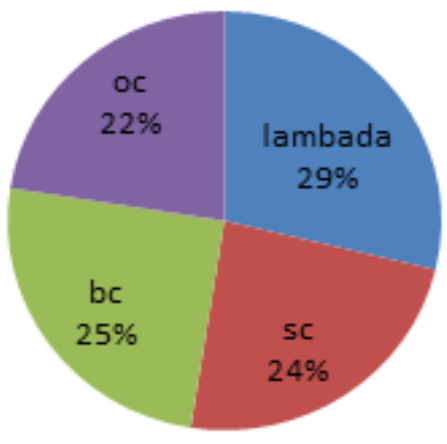

Graph 1. Total Distribution of Cases

\section{Gender distribution in bajara(labada)}

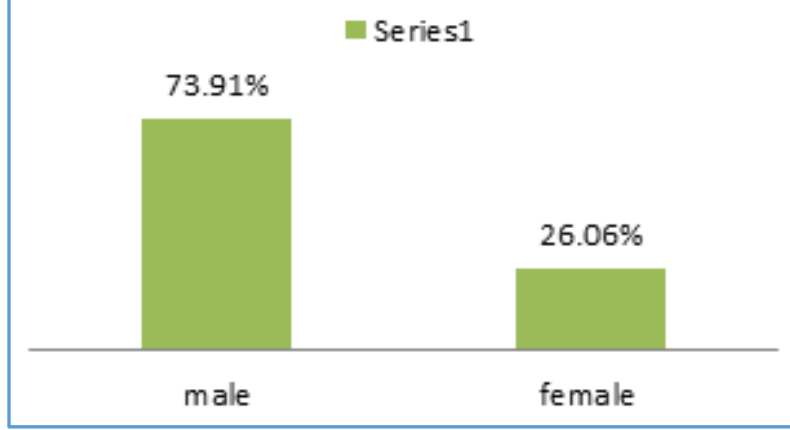

Graph 2. Gender Distribution in Banjara (Lambada) Children

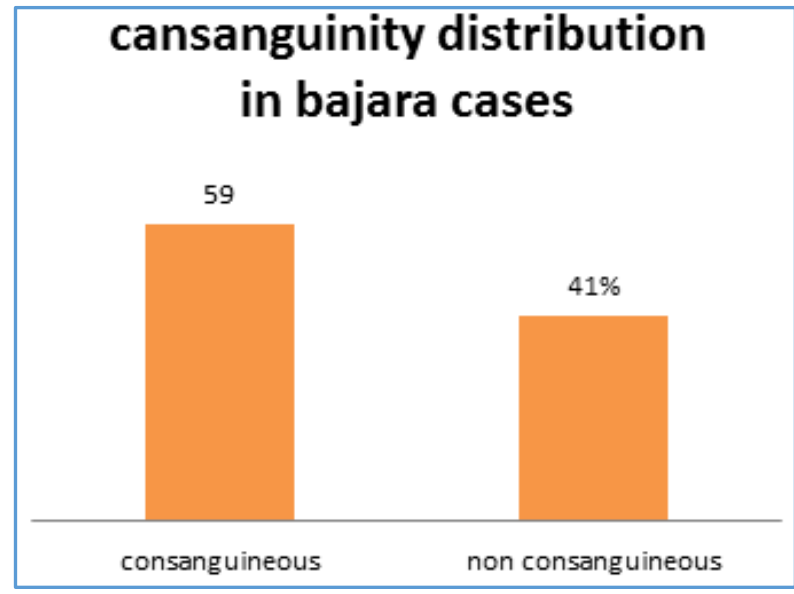

Graph 3. Consanguinity Distribution in Banjara (Lambada) Children 
ratio thalassemia and sickle cell anaemia in bajara children

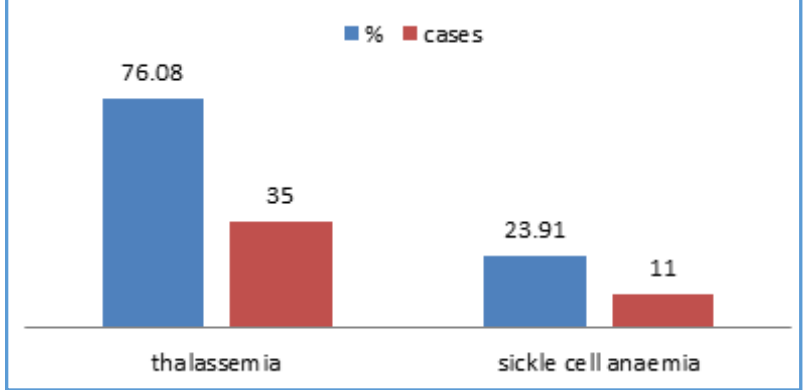

Graph 4. Thalassaemia and Sickle Cell Anaemia in Banjara (Lambada) Children

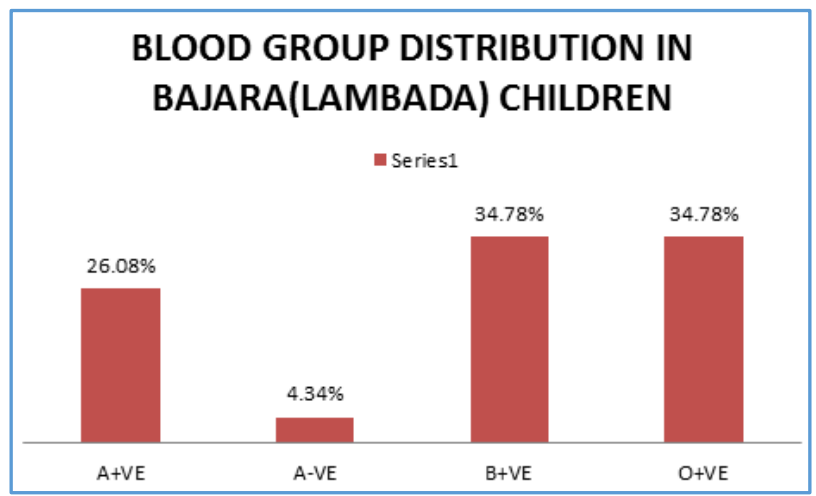

Graph 5. Blood Group Distribution in Banjara Children

\section{DISCUSSION}

The high prevalence rate of haemoglobinopathy and Betathalassaemia in tribal population in India. The sickle cell anaemia and thalassaemia are the most severe form of genetic disorders. Hence, diagnosis of the disease and creating the awareness among the high risk population is very important. In Telangana, tribal population constitutes 9.34 percent, of which Lambada constitutes 62.19 percent. The geographical distribution of sickle cell disorder, Betathalassaemia and other haemoglobinopathies in central eastern parts of India shows the differential migration pattern of the population. Earlier work was done by Naidu et al,[8] Banerjee et al,,[9] Rao et al,[10] Blake et al,[11] Goud et al[12] and Sudhakar Babu et al[13] reported the presence of sickle cell gene among the tribal population from $0-31.79 \%$.

The first multicentre study was done by the Indian Council of Medical Research in the mid-1980s, where high school children from Mumbai in the west, Delhi in North and Kolkata in the East were studied. In this study, the prevalence of Beta-thalassaemia trait was 2.7\% in Mumbai, 5.5\% in Delhi and $10.2 \%$ in Kolkata (Madan et al, 2010).

In our present study, the prevalence of sickle cell anaemia is $23.91 \%$ and thalassaemia is $76.08 \%$ in Lambada group in tribal population respectively.

The studies done among the tribal groups in Orissa showed the prevalence rate of Beta thalassaemia trait from $6.3 \%$ to $8.64 \% .(13,14)$

Out of total thalassaemia reported in India, Betathalassaemia accounts for $80 \%-90 \%$. Beta-thalassaemia is a common haemoglobinopathy in India as per WHO records.
Highest frequency of Beta-thalassaemia trait is reported in Gujarat followed by Sindh, Punjab, Tamilnadu, South India.

In Maharashtra, the sickle gene is widespread in all the eastern districts also known as the Vidarbha region, in the Satpura ranges in the north and in some parts of Marathawada. The prevalence of sickle cell carriers in different tribes varies from 0 to 35 percent.

There are several reports on the spectrum of mutation in different states of India,[15.16] the success of prevention programmes for control of thalassaemia in countries like Cyprus, Italy and Greece have shown that education and screening forms the most important part of these programmes (Angastiniotis et al 1995, Cao et al 2002; Loukopoulos 2011), Diversity in the frequency of Betathalassaemias and carriers of other haemoglobin variant in different countries and hence accurate micro-mapping is important to estimate the disease burden (Weatherall 2011).

No study was done among the Lambada population for the presence of the sickle cell anaemia and Beta-thalassaemia earlier. An attempt was made to know the prevalence of sickle cell anaemia and Beta-thalassaemia among the Lambada community in Warangal district.

\section{CONCLUSION}

There are no studies done so far regarding prevalence of sickle cell anaemia and thalassaemia in Lambada (Banjara) community in Telangana state. This study therefore provides first time the prevalence of disease among the Lambada tribe of Warangal district, Telangana state. The prevalence of haemolytic anaemia is $28.75 \%$ (sickle cell anaemia is $23.91 \%$ and thalassaemia is $76.08 \%$ ) in Lambada population in the present study. In this study, it showed highest prevalence rate seen in single Lambada community. This study is of immense value for future reference and monitoring of these genetic disorders in Lambada (Banjara) population in Telangana state.

\section{REFERENCES}

[1] Balgir RS. The burden of haemoglobinopathies in India and the challenges ahead. Current Science 2000;79(11):1536-47.

[2] Balgir RS. The genetic burden of haemoglobinopathies with special reference to community health in india and the challenges ahead. Indian Journal of Hematology and Blood Transfusion 2002;20:2-7.

[3] Shukla BN, Solanki BR. Sickle cell anaemia in central India. The Lancet 1958;271(7015):297.

[4] Chakravarty G, Urade BP. Haematological profile in sickle cell anaemia and thalassaemia patients in $\mathrm{Vi}$ darbha region of Maharashtra. National Seminar on Human Genomic and Cultural Diversity at School of Stu- dies in Anthropology, Pt. R.S.S. University, Raipur, 2009:2-4.

[5] Balgir RS. Genetic epidemiology of the three predominant abnormal haemoglobins in India. J Assoc Physicians India 1996;44(1):25-8.

[6] Jawahirani A, Mamtani M, Das K, et al. Prevalence of $\beta$ thalassaemia in subcastes of Indian Sindhi: results from a two phase survey. Public Health 2007;121(3):193-8. 
[7] Saha N, Banerjee B. Incidence of abnormal haemoglobins in Punjab. Calcutta Medical Journal 1965;62(3):82-6.

[8] Naidu JM, Mohrenwiser HW, Nee JV. A serobiochemical genetic study of Jalari and Brahmin caste populations of Andhra Pradesh, India. Human Hered 1985;35(3):148-56.

[9] Banerjee SM, Roy B, Dey B, et al. Genetic olymorphism of red cell antigen, enzyme, hemoglobin and serum protein in 15 endogamous populations of South India. J Ind Anthrop Soc 1988;23:250-9.

[10] Rao VR. Genetics and epidemiology of sickle cell anemia in India. Indian J Med Sci 1988;42(9):218-22.

[11] Blake NM, Ramesh A, Vijayakumar M, et al. Genetic studies on some tribes of the Telangana region, A.P., India. Acta Anthropogenet 1981;5(1):41-56.
[12] Goud JD, Rao PR. Genetic studies among the five tribal populations of Andhra Pradesh, South India. Anthrop Anz 1979;37:1-9.

[13] Balgir RS. Spectrum of haemoglobinopathies in the state of Orris, India: a ten years cohort study. JAPI 2005;53:1021-6.

[14] Baldir RS. Genetic heterogenecity of population structure in 15 major schedule tribes in central and eastern India. A study of immune haematological disorders. Indian J Hum Genet 2006;12:86-92.

[15] Verma IC, Saxena R, Thomas E, et al. Regional distribution of beta-thalassemia mutations in India. Hum Genet 1997;100(1):109-13.

[16] Garewal G, Fearon CW, Warren TC, et al. The molecular basis of beta thalassemia in Punjabi and Maharashtran Indians includes a multilocus aetiology involving triplicated alpha-globin loci. Br J Haemotol 1994;86(2):372-6. 